\title{
HAEMOLYSIS IN MALIGNANT BLOOD DISEASES
}

\author{
C. D. R. PENGELly, M.D., M.R.C.P., M.R.C.P.E.* \\ Consultant Physician, North and Mid Cheshire Hospital Group
}

A PREVIOUS paper (Pengelly \& Wilkinson, 1962) described a study of haemolysis in 22 patients with leukaemias, reticuloses and myeloproliferative diseases. The present paper records the results of red-cell survival tests carried out in a further fifteen patients with malignant blood diseases, with some observations on the effects of therapy, in particular the adminstration of adrenocorticosteroids.

\section{Methods}

Red-cell survival was estimated with radioactive chromium $\left({ }^{51} \mathrm{Cr}\right)$ by the method of Mollison and Veall (1955) applied as described by Pengelly and Wilkinson (1962). The terminal red-cell volume was estimated with a further small dose of radioactive chromium $\left({ }^{51} \mathrm{Cr}\right)$ and the graph adjusted as if any change had been a linear one. The mean cell life-span was then estimated by re-plotting the graphs after allowing for ${ }^{51} \mathrm{Cr}$ elution (Method A, Mollison, 1956). Occult blood tests were done on the stools by the method of Needham and Simpson (1952).

\section{Patients Investigated and Tests Applied}

Patients with the following diseases were investigated. All had three negative occult blood tests on the stools before being included in the series. Further occult blood tests were done at intervals of 2 or 3 days throughout the red cell survival tests.

\begin{tabular}{ll}
\multicolumn{1}{c}{ Diagnosis } & Number \\
Chronic myeloid leukaemia & 4 (Cases 1-4) \\
Chronic lymphatic leukaemia & 4 (Cases 5-8) \\
Acute lymphatic leukaemia & 1 (Case 9) \\
Myelomatosis & 1 (Case 10) \\
Reticulosarcoma & 1 (Case 11) \\
Hodgkin's disease & 4 (Cases 12-15)
\end{tabular}

In 13 patients (Cases 2, 3, 4, 5, 6, 7, 8, 9, 11, 12, 13,14 , and 15) the survival of their own red-cells was tested and in three of these (Cases 5.6 and 9), with Group $\mathrm{O}, \mathrm{Rh}$ negative (cde) red-cells also. In three (Cases 12, 13 and 15) the survival test of the patient's own red-cells was repeated during therapy with prednisolone. Case 15 (Hodgkin's disease) had also received $18 \mathrm{mg}$. of nitrogen mustard (Trillekamin) intravenously before the seoond survival test. In two patients (Cases 1 and 10) only Group $\mathbf{O}$,

*Postal Address:' 62 Manchester Road, Altrincham, Cheshire.
Rh negative (cde) red-cells were tested, because both had received a blood transfusion before their own red-cells could be labelled. In one of these patients (Case 1), with chronic myeloid leukaemia, who was already having prednisolone $15 \mathrm{mg}$. daily, the test was repeated while a dose of $40 \mathrm{mg}$. or prednisolone daily was being given. Direct Coombs tests were done in the hospital laboratory in all the patients except Case 3, and in Case 2 antibodies were sought with trypsinised red-cells also. The red-cells and serum of Cases $4,8,11,12,13$ and 15 were submitted to the Manchester Blood Transfusion Centre where a full investigation for antibodies was carried out. (see Table 1).

Apart from Case 15 (Hodgkin's disease) all patients were receiving an appropriate antimitotic agent or agents before the first or only red-cell survival test was started.

\section{Results}

Occult blood tests on the stools were all negative except for an occasional weakly positive result.

Red-cell survival was reduced in 8 patients $(53 \%)-($ Cases $1,2,4,8,11,12,13$ and 15$)$. Mean red-cell life-spans were approximately $40,40,65,55,25,55,60$ and 30 days respectively. Repeat testing was applied in Cases 12 , 13 and 15 during the administration of prednisolone $30 \mathrm{mg}$. daily, and in Case 1 after increasing the dose from 15 to $40 \mathrm{mgs}$. daily. No significant changes occurred in the red-cell life-span except in Case 15 (Hodgkin's disease) where red-cell life-span became normal.

Red-cell survival was normal in the other seven patients (Cases 3, 5, 6, 7, 9, 10 and 14), in Cases 5, 6 and 9 with donor Group $\mathrm{O}, \mathrm{Rh}$ negative (cde) red-cells in addition to the patient's own red-cells.

No significant antibodies were detected in any of the patients and there was no good correlation between reduced red-cell survival and splenic size. The diagnoses, red-cell survival results, approximate initial haemoglobin levels and details of antibody tests and splenic size are given in Table 1.

\section{Discussion}

This paper describes the investigation of fifteen patients with various malignant blood 


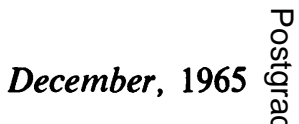

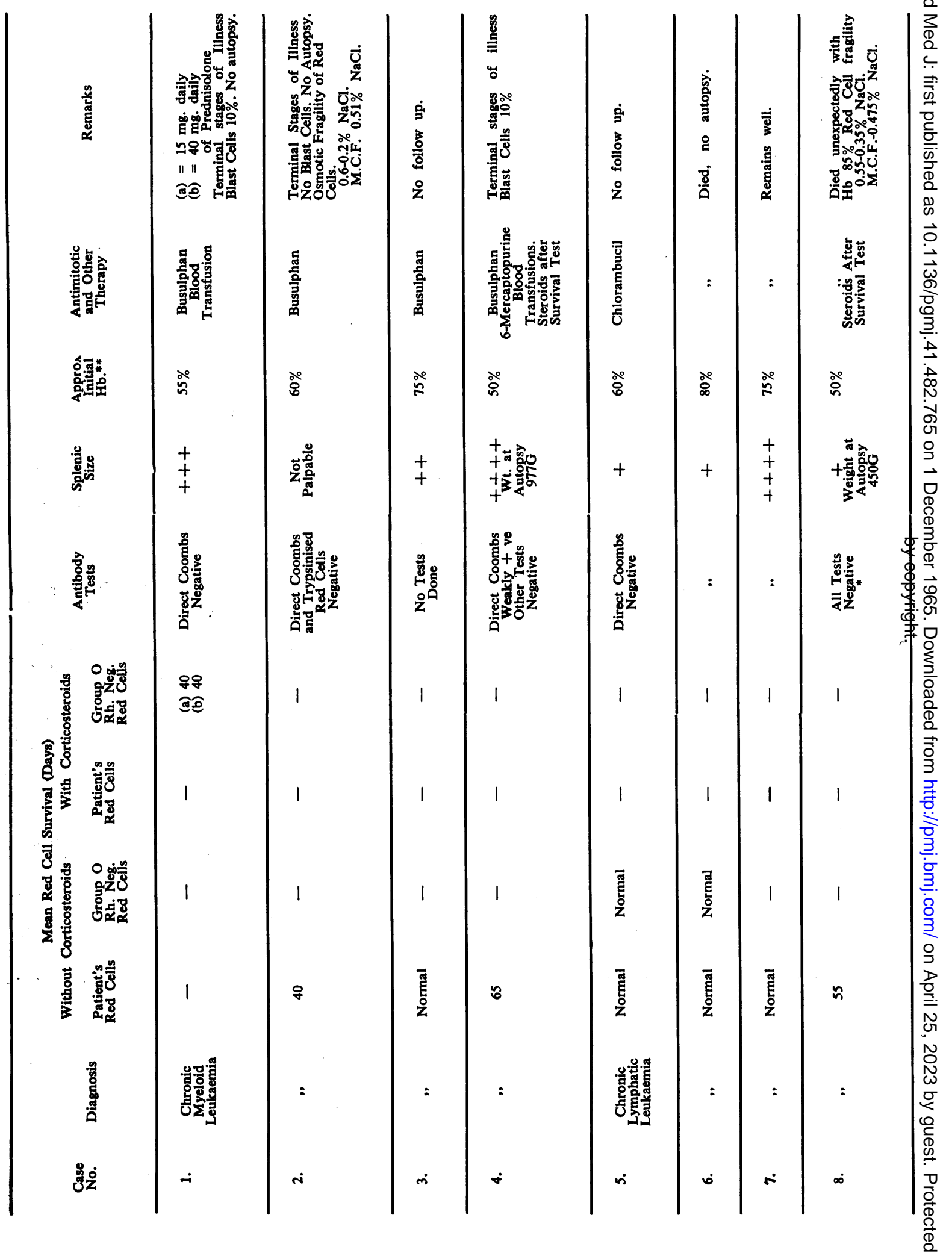




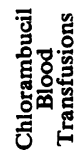

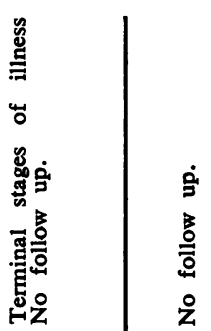

ஓें

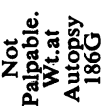

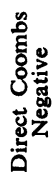

I

ฐँّ

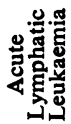

a

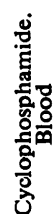

ڤั

z)

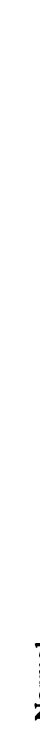

1

$\approx$

8

I

齿

$\leq$
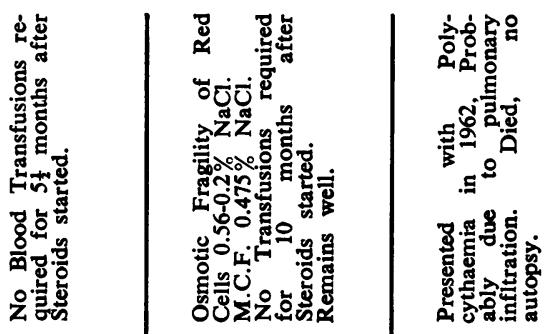

:

す̊

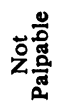

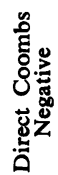

8

8

ฐूँ

요

$\dot{n}$

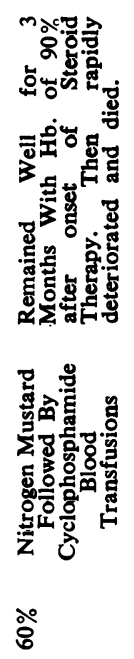

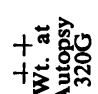

产:

छั้

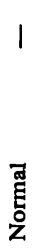

$\dot{m}$

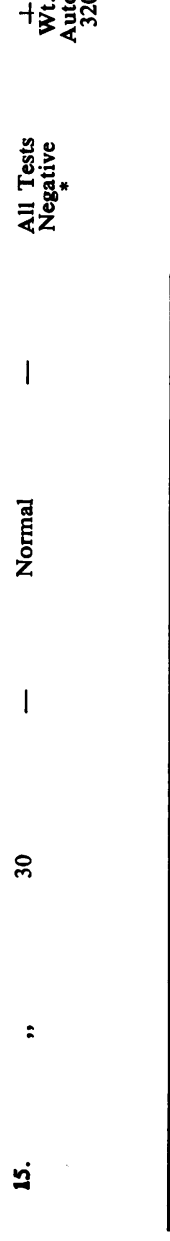

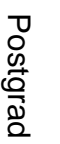

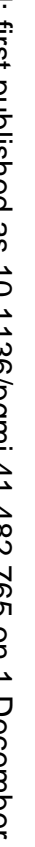

$-8 \frac{0}{2}$

띡웡

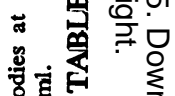

ठ

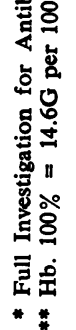

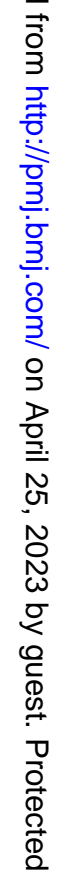


diseases for haemolysis with red-cell survival tests. Reduced red-cell survival was shown in eight patients $(53 \%)$, a considerably higher proportion than in a previous series (Pengelly and Wilkinson, 1962). However, in the present series, there was no attempt to exclude patients who showed evidence of haemolysis without red-cell survival testing.

None of the patients investigated showed any evidence of significant blood loss during the period of investigation and no significant antibodies were demonstrated in any of them.

Adrenocorticosteroids, in addition to appropriate antimitotic therapy, had no definite effect on red-cell survival in three patients (Cases 1, 12 and 13), but in a fourth patient (Case 15) red-cell survival previously considerably reduced, became normal while prednisolone therapy was being given. This patient had received three doses of $6 \mathrm{mg}$. of nitrogen mustard (Trillekamin) between the two survival tests and this may have played a part in the improvement. She did not have any demonstrable antibodies. Although patients 12 and 13 showed no improvement in the red-cell life-span, both were very much improved with prednisolone therapy. Case 12 lived for eight months after the steroid therapy was started and did not require a further blood transfusion for $5 \frac{1}{2}$ months even though 8 units had been required in the previous 6 weeks to maintain a haemoglobin level of about $50 \%$. Case 13 required 8 units of blood in 20 weeks to maintain a haemoglobin level of $50 \%$ before prednisolone was given. Prednisolone therapy was started on November 17th, 1964 and he has since maintained a haemoglobin level of over $60 \%$ and has been doing a heavy labouring job quite easily. No transfusions have been given now for 10 months.

In Case 12 the improvement appeared to be mainly due to increased production of red-cells, as previously observed in a patient with myelofibrosis (Pengelly, 1964). In Case 13 the improvement was apparently mainly due to a considerable drop in the plasma volume which occurred following the steroid therapy. In retrospect a reduction in plasma volume was also a factor in the improvement of the patient with myelofibrosis (Pengelly, 1964). Case 8, a man of 75 (chronic lymphatic leukaemia) at first treated with chlorambucil alone, was improved by the addition of prednisolone therapy, his haemoglobin rising from $55 \%$ to $85 \%$ in seven weeks without transfusions. The cause of this improvement was not clear. A second red-cell survival test was planned but he died rather unexpectedly. No reason for his sudden deterioration was discovered at autopsy.

No obvious clinical benefit arose from the administration of steroids in Case 4.

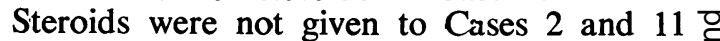
which showed a reduced red-cell life-span. Both of them occurred early in the series and at the time it was not appreciated that any improve- $\stackrel{\mathbb{\Omega}}{\Omega}$ ment might have occurred with steroid therapy in the absence of demonstrable antibodies to the red-cells. Neither were steroids given to Cases $3,5,6,7,9,10$ or 14 whose red-cell life- $\vec{\omega}$ spans were normal. All seemed fairly well clinically without steroid therapy though Case 8 14 (Hodgkin's disease) might have been given 3.

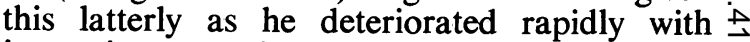
increasing anaemia. He was, however, a patient $\vec{r}$ who declined admission to hospital and whose attendances at the out-patient clinic were ir- or regular and there was eventually little control over his treatment.

No improvement in the red-cell life-span was seen in Case 1 when the dosage of $\mathbb{D}$ steroids was increased from 15 to $40 \mathrm{mg}$. of prednisolone per day. However, the patient was in the terminal stages of the illness (chronio myeloid leukaemia) and only the survival a $\overrightarrow{0}$ Group $\mathrm{Rh}$ negative red-cells was tested. $\mathrm{R}$. duced survival of transfused cells may noi respond to steroids even when the patient's own red-cells are surviving normally (Pengelly, 1964).

Some possible reasons for the haemolysis in $\frac{\circ}{2}$ the absence of antibodies were discussed in $\overrightarrow{\vec{Q}}$ 1962 (Pengelly and Wilkinson, 1962). In add- 을 ition splenic pooling has been shown to play a part in the process of red-cell destruction (Prankerd, 1963), and it seems possible that donor red-cells being antigenically slightly different from the patient's own, even though $\dot{\sigma}$ compatible in vitro, may be pooled by an enlarged spleen and there destroyed.

In conclusion it may be said that it often appears worthwhile giving adrenocorticosteroid 웅 therapy together with an appropriate antimitotic $D$ agent in anaemic patients with leukaemias and reticuloses. Whether or not red-cell antibodies $N$ are demonstrable the survival of the red-cells may be improved when a haemolytic process is present; even if the survival of red-cells does $\omega$ not improve or cannot be improved, red-cell production may be stimulated; also plasma $\bullet$ volume may be reduced, thus allowing even $\mathbb{\Phi}$ an unchanged red-cell mass to increase the patient's haemoglobin level and lessen or abolish the need for blood transfusions. 


\section{Summary}

The results of red-cell survival testing with ${ }^{51} \mathrm{Cr}$ in fifteen patients with various malignant blood diseases are recorded. Reduced red-cell survival was found in 8 cases $(53 \%)$, a higher percentage than in a previous series (Pengelly and Wilkinson, 1962), but there was no attempt to have an unbiased selection of cases in this series. The effects of adrenocorticosteroid combined with antimitotic therapy on red-cell survival are discussed. In no case was a significant titre of red-cell antibodies demonstrated. Nevertheless, in one patient with Hodgkin's disease a greatly reduced red-cell survival test was returned to normal with adrenocorticosteroid and antimitotic therapy, and in two more, although this therapy did not affect the red-cell life-span, the need for transfusions was abolished for long periods and the patient's well-being improved enormously. In another patient, the haemoglobin rose from $55 \%$ to $85 \%$ without a blood transfusion. One patient with Hodgkin's disease is doing quite a heavy job successfully.

The beneficial effect of combined antimitotic and adrenocorticosteroid therapy appears sometimes to be due to increased red-cell survival, sometimes to improved red-cell production and sometimes to a decrease in plasma volume or combinations of these three things. Adrenocorticosteroids combined with appropriate antimitotic therapy therefore seem well worth trying in anaemic patients with leukaemias and reticuloses.

My thanks are due to the physicians of the Manchester Northern Hospital Group and to my colleagues in North and Mid Cheshire for permission to study patients under their care, to Dr. Fred Stratton of the Blood Transfusion Centre, Roby Street, Manchester for the antibody tests, and to the Board of Governors of the Manchester Royal Infirmary and the Manchester Regional Hospital Board for Research Grants. Also to Mr. J. B. Lloyd, Chief Pharmacist, Manchester Royal Infirmary for preparation of sterile bottles and the sterilising of radioactive chromium solutions.

\section{REFERENCES}

Bowdler, A. J., and Prankerd, T. A. J. (1962): Anaemia in the Reticuloses, Brit. med. J., i, 1169

Mollison, P. L. (1956): Blood Transfusion in Clinical Medicine 2nd Ed. p. 139. Oxford: Blackwell Scientific Publications.

Mollison, P. L., and Veall, N. (1955): The Use of Isotope ${ }^{51} \mathrm{Cr}$ as a Label for Red Cells, Brit. J. Haemat., 1, 62.

NeEdHAM, C. D., and Simpson, R. G. (1952): The Benzidine Test for Occult Blood in Faeces, Quart. J. Med. N.S., 21, 123.

Pengelly, C. D. R. (1964): Stimulation of Red CeP Production in Myelofibrosis with Prednisolone Postgrad. med. J., 40, 30.

Pengelly, C. D. R., and Wilkinson, J. F. (1962) The Frequency and Mechanism of Haemolysis i the Leukaemias, Reticuloses and Myeloprolifera? tive Diseases, Brit. J. Haemat., 8, 343.

Prankerd, T. A. J. (1963): The Spleen and Anaemia, Brit. med. J., ii, 517. 